九州大学学術情報リポジトリ

Kyushu University Institutional Repository

\title{
Plant Growth, Seed Yield and Apparent Nutrient Recovery of Rice by the Application of Manure and Fertilizer as Different Nitrogen Sources in Paddy So ils
}

Myint, Aung Kyaw

Laboratory of Plant Nutrition, Division of Bioresource and Bioenvironmental Sciences, Graduate School, Kyushu University

Yamakawa, Takeo

Plant Nutrition Laboratory, Division of Soil Science and Plant Production, Department of Plant Resources, Faculty of Agriculture, Kyushu University

Zenmyo, Takahide

Laboratory of Plant Nutrition, Division of Bioresource and Bioenvironmental Sciences, Graduate School, Kyushu University

https://doi.org/10.5109/16111

出版情報: 九州大学大学院農学研究院紀要. 54 (2)，pp. 329-337，2009-10-29. Faculty of Agriculture, Kyushu University

バージョン :

権利関係 : 


\title{
Plant Growth, Seed Yield and Apparent Nutrient Recovery of Rice by the Application of Manure and Fertilizer as Different Nitrogen Sources in Paddy Soils
}

\author{
Aung Kyaw MYINT ${ }^{1 *}$, Takeo YAMAKAWA ${ }^{2}$ and Takahide ZENMYO ${ }^{1}$ \\ Laboratory of Plant Nutrition, Division of Bioresource and Bioenvironmental Sciences, \\ Faculty of Agriculture, Kyushu University, Fukuoka 812-8581, Japan \\ (Received June 30, 2009 and accepted July 13, 2009)
}

\begin{abstract}
In two different soils, high fertility Kasuya soil and low fertility Futsukaichi soil, both have a fertilization history of low level application using organic manures and fertilizers. In 2007, a pot experiment was conducted in a greenhouse using rice variety Manawthuka to investigate the effect of higher level applications. Cow manure (CM) and poultry manure (PM) were applied as organic nitrogen sources with three levels; 15, 30 and 45 ton ha ${ }^{-1}$ as low, middle and high level for CM and 3, 6 and 9 ton ha ${ }^{-1}$ for PM, respectively. The manure application rates were decided by the estimation of available $\mathrm{N}$ by the calculation. Same rank of application level provided nearly the same available $\mathrm{N}$ amount. In every manure application, $20 \mathrm{~kg}$ urea $\mathrm{ha}^{-1}$ was applied at basal. Urea fertilizer application at the rate of $50 \mathrm{~kg} \mathrm{~N} \mathrm{ha}^{-1}$ (UF) and Japanese standard fertilizer application for rice at the rate of $85: 54: 85 \mathrm{~kg} \mathrm{ha}^{-1}$ of $\mathrm{N}: \mathrm{P}_{2} \mathrm{O}_{5}: \mathrm{K}_{2} \mathrm{O}(\mathrm{J}-\mathrm{std})$ were included. In UF and J-std, three times of split application were carried out at basal, active tillering and panicle initiation stage. Growth characteristics (SPAD value, tiller number and plant height) were recorded during the cultivation period. Dry matter, seed yield and nitrogen $(\mathrm{N})$ uptake were significantly greater in PM compared to CM and the highest in J-std, however no significant different was observed among the levels of CM. Apparent $\mathrm{N}$ recovery was higher in PM compared to CM due to the higher readily available nutrient content and larger major nutrient content of PM. In both soils, the efficiency of CM was very low for the nutrition of rice and only CM application is difficult to get the optimal rice yield by short-term.
\end{abstract}

Keywords: apparent nutrient recovery, cow manure, mixed application, paddy soil, poultry manure, rice

\section{INTRODUCTION}

Rice is the world's most important staple food for more than two billion people in Asia and hundreds of millions in Africa and Latin America (Ladha et al., 1997). Moreover, rice is the main staple food crop in Asia. Within Southeast Asia, rice provides about $60 \%$ of the human food consumption. About $55 \%$ of the Asian rice-producing area is irrigated, and this area produces about $75 \%$ of Asia's total rice production. An estimated 2.2 billion Asian rice farmers and consumers depend upon the sustainable productivity of the irrigated lowland rice ecosystem for their food supply (Buresh et al., 2005).

The wetland rice culture favors fertility maintenance and build-up of organic matter in soils, and is the backbone of long-term sustainability of the wetland rice systems (Sahrawat, 2004). Significant rice farming of the pre-chemical period sustained the nitrogen $(\mathrm{N})$ status of soils by maintaining equilibrium between $\mathrm{N}$ loss of crop harvest and $\mathrm{N}$ gain from biological $\mathrm{N}$ fixation (Ladha and Peoples, 1995). However, in today's intensive rice monocropping systems, this equilibrium has

\footnotetext{
1 Laboratory of Plant Nutrition, Division of Bioresource and Bioenvironmental Sciences, Graduate School, Kyushu University, 6-10-1 Hakozaki, Higashi-ku, Fukuoka 812-8581, Japan

2 Plant Nutrition Laboratory, Division of Soil Science and Plant Production, Department of Plant Resources, Faculty of Agriculture, Kyushu University, 6-10-1 Hakozaki, Higashi-ku, Fukuoka 812-8581, Japan

* Corresponding author (E-mail: niwincho@gmail.com)
}

been disturbed with inputs of mineral fertilizers now playing a significant role (Ladha et al., 2000). The application of chemical fertilizers is costly and gradually lead to the environmental problems. The crop production using organic manures might be superior for physical and chemical properties of the soil and desirable for the sustainable agricultural production. Nowadays, agriculture production based on organic manure application is growing in interest and the demands for the resulting products are increasing. Therefore, the effective use of organic materials in rice farming is also likely to be promoted.

Suzuki (1997) reported that the application of organic materials is fundamentally important in that they supply various kinds of plant nutrients including micronutrients, improve soil physical and chemical properties such as structure, porosity, permeability, cation exchange capacity and hence nutrient holding and buffering capacity, and consequently enhance microbial activities. In addition, organic matter continuously releases $\mathrm{N}$ as plant need it. However, many researchers including Ohyama et al. (1998) Uenosono and Nagatomo (1998) reported that the effects of organic matter application can be observed after more than 3 to 5 years.

Application of animal waste manures, which contain both mineral and organic $\mathrm{N}$, is useful for maintaining and improving soil fertility and rice production (Takahashi et al., 2004). It is very important to understand the fate of $\mathrm{N}$ in the organic materials applied to paddy field. The estimation of $\mathrm{N}$ availability and plant $\mathrm{N}$ recovery for many crop were investigated by many researchers using 
${ }^{15} \mathrm{~N}$-labeled methods. However, the studies on the effect of mixed application of manure and chemical fertilizer and its recovery for rice were very few.

Rice (Oryza sativa L.) variety used in this study was a Myanmar high yielding variety, Manawthuka, which is the most popular one among the local farmers. As a developing country, Myanmar is performing the traditional agriculture commonly based on farmyard manure and low application of chemical fertilizers. Most farmers are performing the mix application of farm yard manure and chemical fertilizer however the amount is reasonably low. In rare cases, no fertilizer application was also observed. Hossain and Singh (2000) reported that the fertilizer application per hectare is low in Myanmar in comparison to the international average. A common dose of $\mathrm{N}$ in the farmer field of rice is about 30 to $60 \mathrm{~kg}$ urea $\mathrm{ha}^{-1}$ although the application of $150 \mathrm{~kg}$ urea $\mathrm{ha}^{-1}$ is also occasionally observed in some area.

To date, food production is accustomed to using of genetically modified and hybrid crops with high chemical fertilizer application because of the world growing population. The comparison between the organic and inorganic fertilizer application on yield and chemical and physical properties of soil is also needed to be clearly examined, even organic farming is commonly suggested as for low productivity.

This study was carried out to: (1) examine the effects of organic manure and inorganic fertilizer application on growth, seed yield and nutrient accumulation of Manawthuka rice, (2) investigate the proper application rate of manures in different fertility paddy soils and (3) investigate the apparent nutrient recoveries (N, P and $\mathrm{K}$ ) of rice as influenced by the mixed application of manure and chemical fertilizer.

\section{MATERIALS AND METHODS}

\section{Pot preparation}

A pot experiment was conducted in a greenhouse at Kyushu University, Japan (33 $37^{\prime} \mathrm{N}, 130^{\circ} 25^{\prime} \mathrm{E}$, at $3 \mathrm{~m}$ AMSL). Two kinds of soil were used, Kasuya soil (clay loam) from Kyushu University farm under yearly rice cultivation, and Futsukaichi soil (sandy loam) which was originally rice cultivated soil but sampled and stored in the laboratory for long time. The sample of Kasuya soil was taken from the upper $20 \mathrm{~cm}$ layer of the field. The selected physicochemical properties of the soils were examined before the experimental set-up and are shown in Table 1. Soil $\mathrm{pH}_{\text {н2о }}\left(1: 2.5\right.$ soil: $\left.\mathrm{H}_{2} \mathrm{O}\right)$ was measured by using a pH meter (Beckman $\Phi 360$ pH/ Temp/ mV Meter). Nutrients content of soils were determined by using salicylic $-\mathrm{H}_{2} \mathrm{SO}_{4}-\mathrm{H}_{2} \mathrm{O}_{2}$ digestion (Ohyama et al., 1991) followed by indophenol method (Cataldo et al., 1974) for total N, ascorbic acid method (Murphy and Riley, 1962) for total phosphorus (P) and atomic absorption spectrophotometer (Z-5300, Hitachi) for total potassium (K). Cation exchange capacity (CEC) and exchangeable cations were determined by ammonium acetate shaking extraction method (Muramoto et al., 1992) followed by atomic absorption spectrophotometer (Z-5300, Hitachi).
Table 1. Selected physicochemical properties of the soil samples before pot study

\begin{tabular}{lcc}
\hline \multicolumn{1}{c}{$\begin{array}{c}\text { Physicochemical } \\
\text { property }\end{array}$} & $\begin{array}{c}\text { Kasuya } \\
\text { soil }\end{array}$ & $\begin{array}{c}\text { Futsukaichi } \\
\text { soil }\end{array}$ \\
\hline Bulk density & 1.17 & 1.25 \\
Soil pH $\left(\mathrm{H}_{2} \mathrm{O}\right)$ & 5.73 & 6.11 \\
Total N $\left(\mathrm{g} \mathrm{kg}^{-1}\right)$ & 1.51 & 0.68 \\
Total P $\left(\mathrm{g} \mathrm{kg}^{-1}\right)$ & 1.00 & 0.37 \\
Total K $\left(\mathrm{g} \mathrm{kg}^{-1}\right)$ & 6.65 & 4.06 \\
CEC $\left(\mathrm{cmol} \mathrm{kg}^{-1}\right)$ & 12.11 & 9.75 \\
Exc. Ca $\left(\mathrm{cmol} \mathrm{kg}^{-1}\right)$ & 12.47 & 10.76 \\
Exc. Mg $\left(\mathrm{cmol} \mathrm{kg}^{-1}\right)$ & 1.81 & 0.89 \\
Exc. K $\left(\mathrm{cmol} \mathrm{kg}^{-1}\right)$ & 0.49 & 0.32 \\
Exc. $\mathrm{Na}\left(\mathrm{cmol} \mathrm{kg}^{-1}\right)$ & 0.99 & 0.14 \\
Exc. Fe $\left(\mathrm{cmol} \mathrm{kg}^{-1}\right)$ & 0.10 & 0.10 \\
Exc. Mn $\left(\mathrm{cmol} \mathrm{kg}^{-1}\right)$ & 0.03 & 0.00 \\
\hline
\end{tabular}

Abbreviation: CEC, cation exchangeable capacity; Exc., exchangeable.

In 2005 May, soils were ground to pass $2 \mathrm{~mm}$ sieve and put $3.5 \mathrm{~kg}$ each into the $3 \mathrm{~L}$ plastic pots. Rice cultivation was carried out once a year (June to October) for two years (2005-2006) and after every harvesting, the underground portion of the rice plant (stubbles) was cut into small pieces and incorporated with soil and irrigated once to favor the organic matter decomposition. Our report is under the scope of 2007 rice cultivation by manure and fertilizer application.

\section{Treatments and experimental design}

In this study, fermented cow manure (CM) and poultry manure (PM) were used as organic $\mathrm{N}$ source. To understand the chemical properties of the manures, total $\mathrm{N}$, total $\mathrm{P}$ and total $\mathrm{K}$ contents were determined as described above. Total carbon content was determined on a Yanaco CHN corder (MT-5). The chemical properties of manures are shown in Table 2. As the previous fertilization history, manures were applied as 5 to 15 ton $\mathrm{ha}^{-1}$ for $\mathrm{CM}$ and 1 to 3 ton ha ${ }^{-1}$ for PM in 2005-2006 rice cultivations. In this study, three levels of manure were applied as low level of 15 ton $\mathrm{ha}^{-1}$ (CM1), middle level of 30 ton ha ${ }^{-1}$ (CM2) and high level of 45 ton ha ${ }^{-1}$ (CM3) for $\mathrm{CM}$, and low level of 3 ton $\mathrm{ha}^{-1}$ (PM1), middle level of

Table 2. Chemical properties of manures

\begin{tabular}{lcc}
\hline Characteristic & $\begin{array}{c}\text { Cow } \\
\text { manure }\end{array}$ & $\begin{array}{c}\text { Poultry } \\
\text { manure }\end{array}$ \\
\hline Total $\mathrm{N}\left(\mathrm{g} \mathrm{kg}^{-1}\right)$ & 13.4 & 26.7 \\
Total P $\left(\mathrm{g} \mathrm{kg}^{-1}\right)$ & 2.5 & 36.6 \\
Total K $\left(\mathrm{g} \mathrm{kg}^{-1}\right)$ & 7.7 & 45.4 \\
Total C $\left(\mathrm{g} \mathrm{kg}^{-1}\right)$ & 296.0 & 218.5 \\
C/N ratio & 22 & 8 \\
\hline
\end{tabular}

All data are in dry weight basis 
6 ton $\mathrm{ha}^{-1}$ (PM2) and high level of 9 ton ha $\mathrm{h}^{-1}$ (PM3) for PM. The application amounts (ton ha ${ }^{-1}$ ) were estimated by soil weight basis (volume $\times$ bulk density). The manure levels were decided based on the estimation of $\mathrm{N}$ availability of manures as 30\% of total $\mathrm{N}$ content in $\mathrm{CM}$ and $70 \%$ of that in PM (Castellanos and Pratt, 1981; Kelling et al., 1998) and to ensure that the same rank in the level of both manures providing the same available $\mathrm{N}$ nutrition. The basal application of $20 \mathrm{~kg}$ urea ha $\mathrm{has}^{-1}$ warried out in all manure treatments to get the well-stand seedling and to stimulate the decomposition of applied manures. Therefore, it has to be considered that the every manure treatment was modified by the same addition of urea. Inorganic fertilizer treatments with urea (UF) at the rate of $50 \mathrm{~kg} \mathrm{ha}^{-1}$ (common average inorganic fertilizer application in rice of ordinary farmer field in Myanmar) and Japanese standard for rice (J-std) at the rate of 85:54:85 kg ha-1 of $\mathrm{N}: \mathrm{P}_{2} \mathrm{O}_{5}: \mathrm{K}_{2} \mathrm{O}$ were compared to manure applications. No application (control) was also included. In UF and J-std, three split applications were carried out at basal, active tillering and panicle initiation stage. The pots were arranged in a completely randomized design with three replicates.

\section{Rice cultivation}

Rice variety Manawthuka (Indica, Myanmar high yielding variety) was used after examination of their suitability and optimal growth in Japanese environment. This variety is the most popular variety in Myanmar for its high yield potential and wide adaptability and, therefore, used more than 90\% of Myanmar farmers, especially in monsoon season. Rice seedlings were prepared by using commercial seedbed soil (Kokuryu Baido, Seisin sangyo Co., Kitakyushu, Japan). The nutrient content of seedbed soil is $0.28 \mathrm{~g} \mathrm{~N}$ : $0.28 \mathrm{~g} \mathrm{P}_{2} \mathrm{O}_{5}: 0.28 \mathrm{~g} \mathrm{~K} \mathrm{~K}_{2} \mathrm{O}$ per $\mathrm{kg}$ soil. The pots were flooded with water immediately after the application of manures and fertilizers and kept for three days prior to transplantation. A 21-day-old seedling was transplanted per pot in May 21, 2007. Irrigation was carried out using tap water and the water level was maintained at $3-5 \mathrm{~cm}$ above the soil surface until maturity.

During the rice cultivation period, SPAD value, tiller number and plant height was recorded weekly in fastgrowing stage (10 to 75 DAT: days after transplanting) and at 2 weeks interval afterwards. SPAD value was measured using a chlorophyll meter (SPAD-502, Konica Minolta Sensing Inc., Osaka, Japan). The uppermost fully expanded leaf was used to measure the SPAD value before the panicle initiation stage and the flag leaf after that.

\section{Plant sampling and analysis}

At maturity, rice plants were cut at $2-3 \mathrm{~cm}$ above ground and dry matter weight, seed weight were determined. Harvested seed weight was estimated at 14\% moisture content. Nutrient accumulation in plant, separately in the straw, seed and husk, was analyzed after $\mathrm{H}_{2} \mathrm{SO}_{4}-\mathrm{H}_{2} \mathrm{O}_{2}$ digestion (Ohyama et al., 1991) followed by the methods mentioned above for total $\mathrm{N}$, total $\mathrm{P}$ and total $\mathrm{K}$

\section{$\mathrm{N}$ input-output balance and apparent nutrient recovery}

The $\mathrm{N}$ input-output balance was simply examined by subtraction of total plant $\mathrm{N}$ accumulation from total $\mathrm{N}$ application. The apparent recovery method contrasts rice nutrient uptake in treatments and control (Motavalli et $a l ., 1989)$. It is assumed that each soil provides the same amount of nutrient elements to all respective soils and an additional whole plant uptake above each control is result of the treatment. The apparent nutrient recovery is calculated using the following equation:

Apparent nutrient recovery $(\%)=($ Treatment nutrient uptake - Control nutrient uptake)/ Total nutrient applied $\times 100$

In above equation, the uptake represents the aboveground whole plant nutrient element accumulation. The apparent recoveries of major nutrient elements $(\mathrm{N}, \mathrm{P}$ and $\mathrm{K}$ ) were examined in our study.

\section{Statistical analysis}

Analysis of variance (ANOVA) to test the statistical significance and Tukey HSD (honestly significant difference) test to calculate the least significant difference (LSD) at 5\% probability level were conducted using JMP software (JMP IN, Version 5.0.1 a, SAS Institute Inc., Cary, NC, USA).

\section{RESULTS}

\section{Plant growth characters}

Plant growth characters (SPAD value, tiller number and plant height) were different among the treatments
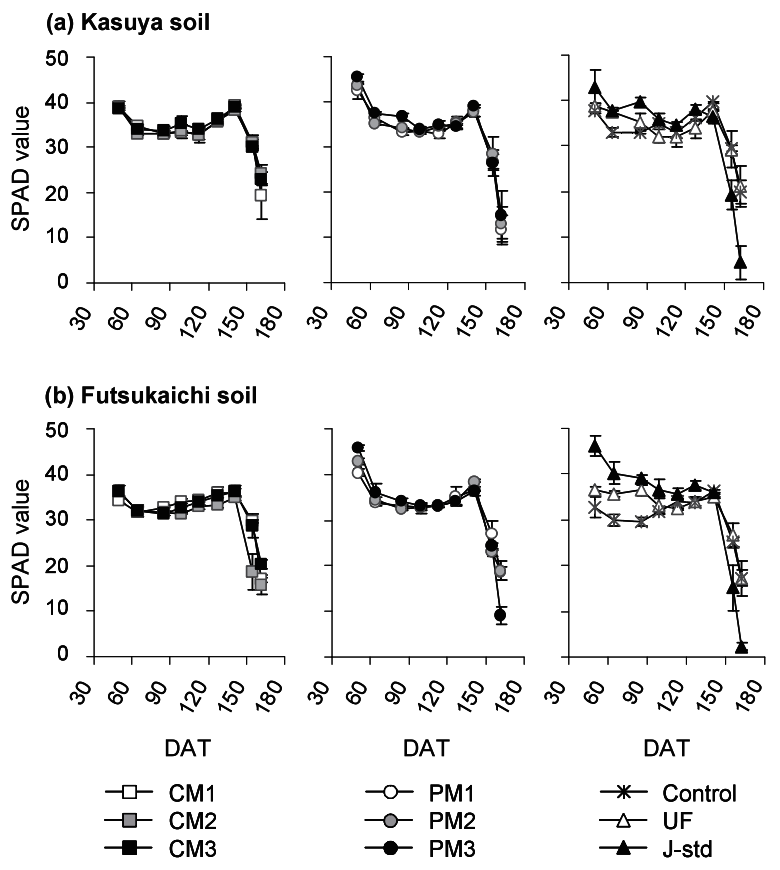

Fig. 1. Changes in SPAD value with different manures and fertilizer application in (a) Kasuya soil and (b) Futsukaichi soil. Bar on each symbol indicates standard deviation. 


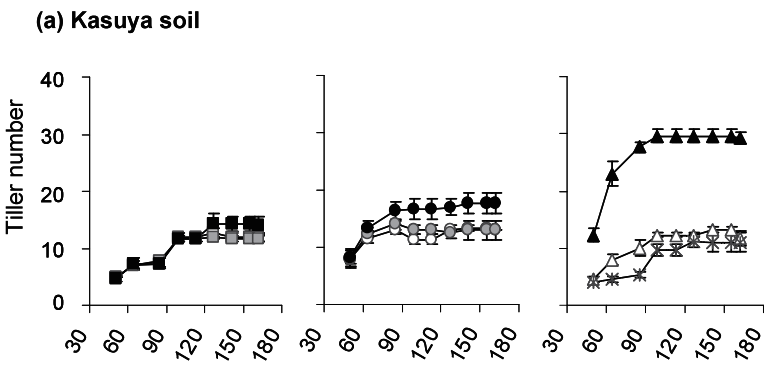

(b) Futsukaichi soil

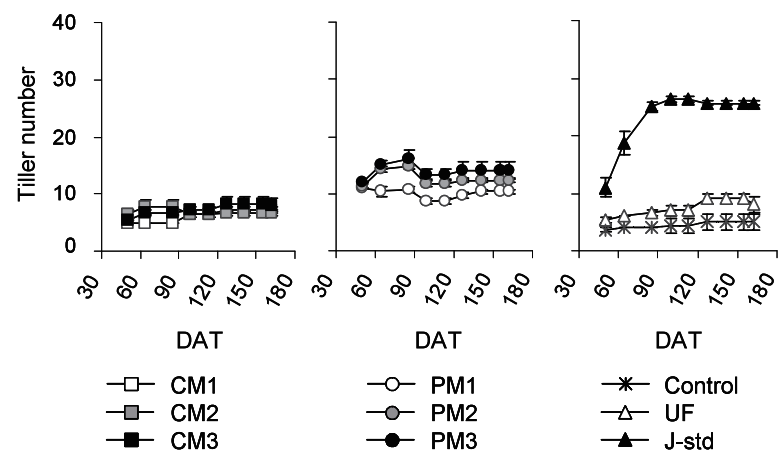

Fig. 2. Changes in tiller number with different manures and fertilizer application in (a) Kasuya soil and (b) Futsukaichi soil. Bar on each symbol indicates standard deviation.

and higher in applications compared to control in both soils, showing the response of manures and fertilizer. Generally, SPAD value was obviously different among the treatments and between two soils at the beginning of investigation (60 DAT) (Fig. 1). The greater values were observed in PM in comparison to $\mathrm{CM}$ and they were higher in Kasuya soil than in Futsukaichi soil while the lowest was observed in the control of both soils. However, SPAD value was higher in Futsukaichi soil for J-std. SPAD value gives the relative chlorophyll content of the rice leaf and in this study it ranged between 30 and 50 through out the cropping seasons for both years except control (Fig. 1). The value was decreased after 60 DAT in all manure applications. In contrast, the decreasing was unusual in J-std and UF. In heading stage (around 140 DAT) temporary increasing of SPAD value was observed in all treatments. The highest tiller numbers were observed in J-std in both soils and significantly different among the treatments (Fig. 2). Relatively lower tiller number was obtained in control and in CM applications of Futsukaichi soil. The decreasing of number was detected in PM treatments of Futsukaichi soil due to tiller death. Plant height (data not shown) was also contributed the same pattern with SPAD value and tiller number, highest in J-std and lowest in control while higher in PM compared to CM.

\section{Dry matter accumulation, harvested seed weight}

Dry matter weight and grain yield were significantly different among the treatments and significantly higher in Kasuya than Futsukaichi soil $(P<0.05)$ except PM2 and PM3 (Fig. 3, 4 and Table 3). There was no significant difference among the levels of CM applications for both soils. On the other hand, the higher level application gave

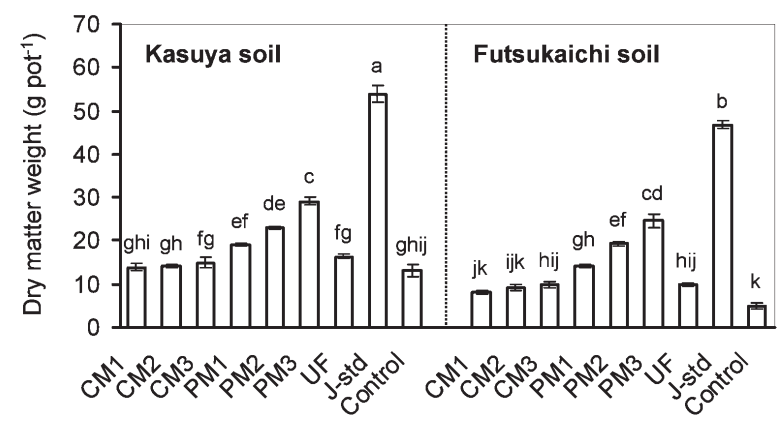

Fig. 3. Effects of manures and fertilizer application on dry matter accumulation in two different fertility soils. The histograms with the same letter in same case are not significantly different according to Tukey HSD test $(P<0.05)$.

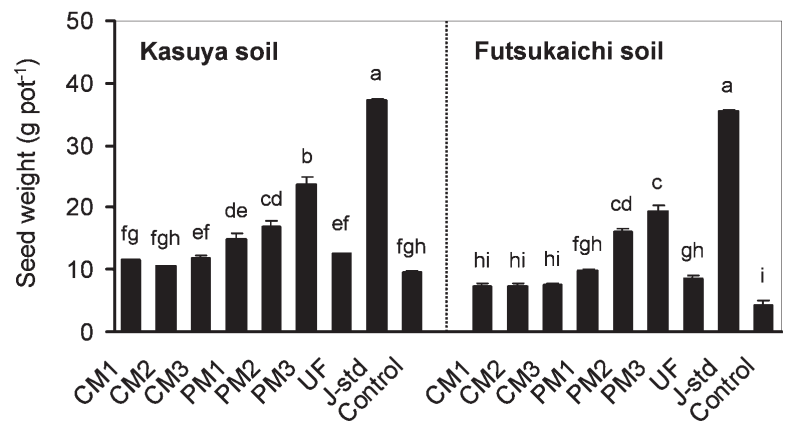

Fig. 4. Effects of manures and fertilizer application on harvested seed weight in two different fertility soils. The histograms with the same letter in same case are not significantly different according to Tukey HSD test $(P<0.05)$.

Table 3. Probability values using two-way ANOVA of each parameter

\begin{tabular}{lcc}
\hline & Dry matter & $\begin{array}{r}\text { Harvested } \\
\text { seed weight }\end{array}$ \\
\hline \multicolumn{2}{c}{$P$ value } \\
Soil & $<0.0001$ & $<0.0001$ \\
Treatment & $<0.0001$ & $<0.0001$ \\
Soil $\times$ Treatment & 0.3194 & 0.0096 \\
\hline
\end{tabular}

the significantly higher $(P<0.05)$ dry matter weight in PM applications (Table 3). UF gave the higher dry matter than control, however significantly lower than PM and J-std. Dry matter weight was the highest in J-std of both soils and 316\% and 852\% higher than respective controls. Dry matter weight in control of Kasuya soil was $163 \%$ higher than that of Futsukaichi soil (Fig. 3). The same pattern of distributions was also detected in harvest seed weight (Fig. 4 and Table 3). However, there was no significant different in harvest seed weight between J-std applications of two soils.

\section{Major nutrient accumulation and apparent nutri- ent recoveries}

The total accumulation of elements in the whole upper ground portion of the plant represented the plant nutrient accumulation. It was calculated by the summa- 
Table 4. Total plant accumulation and apparent recovery of major nutrients in rice by manures and fertilizer application in two different soils

\begin{tabular}{|c|c|c|c|c|c|c|}
\hline & \multicolumn{3}{|c|}{ Total plant accumulation $\left(\mathrm{mg} \mathrm{pot}^{-1}\right)$} & \multicolumn{3}{|c|}{ Apparent nutrient recovery (\%) } \\
\hline & $\mathrm{N}$ & $\mathrm{P}$ & $\mathrm{K}$ & ANR & APR & AKR \\
\hline \multicolumn{7}{|l|}{ Kasuya soil } \\
\hline CM1 & $126.6 \mathrm{fgh}$ & $18.3 \mathrm{ef}$ & 369.8 fgh & $11.4 \mathrm{c}$ & $4.3 \mathrm{~d}$ & $22.3 \mathrm{~b}$ \\
\hline CM2 & 121.3 fghi & $17.7 \mathrm{ef}$ & 376.9 fg & $4.6 \mathrm{c}$ & $1.6 \mathrm{~d}$ & $13.3 \mathrm{~b}$ \\
\hline CM3 & $134.2 \mathrm{efg}$ & $18.6 \mathrm{ef}$ & 498.5 ef & $6.0 \mathrm{c}$ & $1.7 \mathrm{~d}$ & $33.8 \mathrm{~b}$ \\
\hline PM1 & 177.2 de & $24.7 \mathrm{~cd}$ & 589.6 de & $48.4 \mathrm{~b}$ & $2.8 \mathrm{~d}$ & $66.3 \mathrm{~b}$ \\
\hline PM2 & $209.5 \mathrm{~d}$ & $27.8 \mathrm{c}$ & $709.7 \mathrm{~cd}$ & $39.7 \mathrm{~b}$ & $1.9 \mathrm{~d}$ & $48.7 \mathrm{~b}$ \\
\hline PM3 & $279.3 \mathrm{c}$ & $36.7 \mathrm{~b}$ & $1084.3 \mathrm{~b}$ & $46.4 \mathrm{~b}$ & $2.2 \mathrm{~d}$ & $64.8 \mathrm{~b}$ \\
\hline UF & $144.8 \mathrm{ef}$ & $22.3 \mathrm{de}$ & $409.2 \mathrm{efg}$ & $47.3 \mathrm{~b}$ & - & - \\
\hline J-std & $464.4 \mathrm{a}$ & $61.0 \mathrm{a}$ & $1332.7 \mathrm{a}$ & $120.2 \mathrm{a}$ & $54.6 \mathrm{~b}$ & $404.6 \mathrm{a}$ \\
\hline Control & 106.7 fghij & $16.0 \mathrm{fgh}$ & $333.5 \mathrm{fgh}$ & - & - & - \\
\hline \multicolumn{7}{|l|}{ Futsukaichi soil } \\
\hline CM1 & $73.7 \mathrm{jk}$ & $10.7 \mathrm{ij}$ & 302.9 fgh & $16.9 \mathrm{c}$ & $7.7 \mathrm{c}$ & $80.7 \mathrm{~b}$ \\
\hline CM2 & 79.4 hijk & $11.6 \mathrm{hi}$ & 319.0 fgh & $11.1 \mathrm{c}$ & $4.7 \mathrm{~cd}$ & $45.3 \mathrm{~b}$ \\
\hline CM3 & $77.4 \mathrm{ijk}$ & $11.8 \mathrm{hi}$ & 349.6 fgh & $7.3 \mathrm{c}$ & $3.3 \mathrm{~d}$ & $36.5 \mathrm{~b}$ \\
\hline PM1 & 113.3 fghij & $17.1 \mathrm{fg}$ & $483.3 \mathrm{efg}$ & $47.4 \mathrm{~b}$ & $3.4 \mathrm{~d}$ & $80.7 \mathrm{~b}$ \\
\hline PM2 & $175.4 \mathrm{de}$ & $24.8 \mathrm{~cd}$ & $700.4 \mathrm{~cd}$ & $50.7 \mathrm{~b}$ & $2.9 \mathrm{~d}$ & $68.4 \mathrm{~b}$ \\
\hline PM3 & $214.2 \mathrm{~d}$ & $29.5 \mathrm{c}$ & $848.2 \mathrm{c}$ & $45.7 \mathrm{~b}$ & $2.4 \mathrm{~d}$ & $58.4 \mathrm{~b}$ \\
\hline $\mathrm{UF}$ & 89.0 ghijk & $12.7 \mathrm{ghi}$ & $291.1 \mathrm{gh}$ & $55.6 \mathrm{~b}$ & - & - \\
\hline J-std & $416.1 \mathrm{~b}$ & $56.5 \mathrm{a}$ & $1155.2 \mathrm{ab}$ & $125.0 \mathrm{a}$ & $60.4 \mathrm{a}$ & $398.3 \mathrm{a}$ \\
\hline Control & $44.2 \mathrm{k}$ & $6.6 \mathrm{j}$ & $171.6 \mathrm{~h}$ & - & - & - \\
\hline \multicolumn{7}{|c|}{ Source of variance (P value) } \\
\hline Soil & $<0.0001$ & $<0.0001$ & $<0.0001$ & 0.0162 & $<0.0001$ & 0.0310 \\
\hline Treatment & $<0.0001$ & $<0.0001$ & $<0.0001$ & $<0.0001$ & $<0.0001$ & $<0.0001$ \\
\hline Soil $\times$ Treatment & 0.7055 & 0.1229 & 0.1377 & 0.6315 & 0.0011 & 0.2171 \\
\hline
\end{tabular}

Means followed by same letter in each column are not significantly different by the Tukey HSD test $(P<0.05)$.

Abbreviation: ANR, apparent N recovery; APR, apparent P recovery; AKR, apparent K recovery.

tion of nutrient contents in straw, grain and hull determined separately. The $\mathrm{N}$ accumulations were significantly different between soils and among the applications (Table 4). The total plant $\mathrm{N}$ accumulation was significantly higher $(P<0.05)$ in Kasuya soil than in Futsukaichi soil for all treatments (Table 4). Higher plant N accumulations were observed in PM applications with a range of 177.2 to $279.3 \mathrm{mg}^{\mathrm{pot}^{-1}}$ in Kasuya soil and 113.3 to $214.2 \mathrm{mg} \mathrm{pot}^{-1}$ in Futsukaichi soil. In contrast, those were significantly lower $(P<0.05)$ in $\mathrm{CM}$ application with the range of 121.3 to $134.2 \mathrm{mg} \mathrm{pot}^{-1}$ in Kasuya soil and 73.7 to $79.4 \mathrm{mg} \mathrm{pot}^{-1}$ in Futsukaichi soil. There was no significant difference of total $\mathrm{N}$ accumulation $(P<0.05)$ among the levels of CM for both soils (Table 4 ). The $\mathrm{N}$ accumulation in overall levels of CM application was lower than that in UF, N application in which is lower than all levels in manure-fertilizer mixed applications. The control gave the lowest plant $\mathrm{N}$ accumulation among all treatments in both soils.

The total plant accumulations of $\mathrm{P}$ and $\mathrm{K}$ were significantly different $(P<0.05)$ among the application treatments (Table 4). Significantly higher plant accumulation of $\mathrm{P}$ and $\mathrm{K}$ were observed in $\mathrm{PM}$ than $\mathrm{CM}$ application.
There was no application of $\mathrm{P}$ and $\mathrm{K}$ in UF, however, higher plant accumulation was observed especially in Futsukaichi soil. The lowest $\mathrm{P}$ and $\mathrm{K}$ accumulation was obtained in controls of both soils while the highest in J-std wherein the P and K applications were carried out.

Apparent N recovery (ANR) was the highest in J-std among all treatments and 120.2 and $125.0 \%$ respectively in Kasuya and Futsukaichi soil. The PM application and UF gave significantly higher ANR than CM in both soils. There was no significant difference $(P<0.05)$ between the same treatments in both soils. The apparent $\mathrm{P}$ recovery (APR) was highest in J-std compared to all treatments and higher amount of APR was observed in CM application compared to PM and UF especially in Futsukaichi soil. Obviously higher apparent $\mathrm{K}$ recovery (AKR) was examined in J-std treatment in comparison to all other manure and fertilizer applications. There was no significant different AKR $(P<0.05)$ among the levels and kinds of manure applications.

\section{DISCUSSION}

Two kinds of soil using for rice cultivation in our 
study were greatly different in physical and chemical properties (Table 1). Original soil fertility affected largely on the growth and yield of rice in the previous years, 2005-2006 with greater contributions in Kasuya soil than Futsukaichi soil (Myint et al., 2009). However, after three years cultivation with continuous manure applications, the difference of plant growth, seed yield and nutrient accumulations between the good and poor fertility soils became small. That might be due to residual effects of manure and fertilizer application with suitable management procedures for organic matter decomposition and the using of higher manure amounts in 2007.

The SPAD value, the most important one of plant growth characteristics, was highly correlated with leaf N and chlorophyll content of the paddy rice. Paddy rice plants do not contain any significant amount of nitrate (differ from upland crops) and therefore, their $\mathrm{N}$ status can be easily determined by SPAD value (Takebe and Yoneyama, 1989). Peng et al. (1996) focused on determination of a chlorophyll meter reading (SPAD value) that farmers could refer to in the field. They suggested the use of 35 as a critical SPAD value for an IRRI high yielding cultivar, IR72, in the dry season and recommended a topdressing of $30 \mathrm{~kg} \mathrm{~N}$ ha ${ }^{-1}$ whenever SPAD value fall below this number. In our study, the SPAD values were generally lower than 35 in $\mathrm{CM}$ applications and control through out the growing season, while almost 35 in PM and UF applications and higher than 35 in J-std in both soils. Therefore, this result suggests that the available $\mathrm{N}$ in two soils with $\mathrm{CM}$ application might be lower than that needed by the crop. However, a critical threshold value of SPAD for Manawthuka is needed to refer in the field to get an optimal rice production and further studies will be necessary.

In Manawthuka rice, with the manure and fertilizer application, two times of SPAD value increasing was observed; one at the beginning of growing period and the other at heading stage (about 140 DAT) (Fig. 1). The increasing of SPAD value at about 60 DAT was due to the higher nutrient availability by manure and fertilizer applications. After that period, decreasing of SPAD value was observed due to decreasing of nutrient availability. However, a temporary increasing of SPAD value at about 140 DAT might be due to the characteristics of Manawthuka (indica). Yoshida (1981) reported that adequate amount of $\mathrm{N}$ is required for growing of young panicle at the panicle initiation period, and nitrogen absorbed at this time is efficiently used to increase spikelet number and panicle size. In a field experiment using an indica inbred rice cultivar (IR72) and tropical hybrid rice (IR68284H), Peng et al. (1998) found that N content and SPAD value of flag leaf in IR72 at flowering stage was increased compared to other growth stage and higher than that in IR68284H. Turner and Jund (1994) also found that the SPAD values of low $\mathrm{N}$ applied rice were increase (about 35) at heading stage in a study using different rates of $\mathrm{N}$ application, and they explained that the lower leaf of the plant with lower $\mathrm{N}$ application caused to senesce and translocate $\mathrm{N}$ to flag leaf, resulting in a greener flag leaf. Yoshida (1981) reported that rice leaf $\mathrm{N}$ content is influenced by climate, soil, amount and type of fertilizer, cultivar and cultural practices. At heading stage, SPAD value and $\mathrm{N}$ content in flag leaf has a poor correlation with plant $\mathrm{N}$ demand and they were dependent on the growth stage and cultivar (Turner and Jund, 1994; Hussain et al., 2000; Yoshida, 1981). Therefore, in our study the SPAD value increasing in flag leaf in Manawthuka can also be assumed as a varietal characteristic and further systematic investigation will be needed.

Tiller numbers, dry matter and harvested seed weight were different with different manure and fertilizer applications (Fig. 2, 3 and 4) and those were highest in J-std in both soils and it is indicating that the application of $\mathrm{N}$, $\mathrm{P}$ and $\mathrm{K}$ in adequate amount provided the highest optimal yield. By reviewing the growth characteristics, the number of effective tiller performed the significant role of rice seed yield in quantity. In PM applications of Futsukaichi soil, decreasing of tiller number was observed due to tiller death, it might be a result of inadequacy of nutrient element during the active growing stage (Fig. 2). In a general view, the efficiency of CM applications was very low especially in Futsukaichi soil. Therefore, the using of CM as a sole application will be difficult to get suitable growth and yield of rice.

In manure applications of both soils, PM provided the higher crop growth, dry matter accumulation and seed yield. It might be due to the higher nutrient availability and high major nutrients content (such as N, P and K) of PM. Sims and Wolf (1994) reported that nutrient contents of PM are among the highest of all animal manures, and the use of PM as soil amendment for agricultural crops will provide appreciable quantities of all important plant nutrients. In UF, higher SPAD value was observed in both soils (Fig. 1) and the dry matter and seed yield (Fig. 3 and 4) were similar to those in CM with 2- to 6 -times higher $\mathrm{N}$ application. It suggests that the split application of chemical fertilizer (UF) efficiently promote the crop growth although the amount was very low. Savant and DeDatta (1982) reported that plant recovery of topdressed nitrogen was always higher because it was applied when the root system was well developed. All parameters investigated in this study indicate that the effects of J-std application were among the highest and it was due to its recommendation as a standard and for doing split application.

The amount of total $\mathrm{N}$ in low levels of manure application (CM1 and PM1) was twice of that in UF and that in middle levels of manure application (CM2 and PM2) was nearly the same with that in J-std, although application amounts were decided by the estimation of $\mathrm{N}$ availability percentage. Therefore, total accumulation of $\mathrm{N}, \mathrm{P}$ and $\mathrm{K}$ in rice was not directly related to the amount of total nutrient in applications and it might be depend on the kinds of manure and fertilizer and their nutrient availability. PM enhanced the more nutrient accumulation compared to $\mathrm{CM}$ in both soils (Table 4). In inorganic fertilizer application (UF and J-std), plant accumulation was higher than total application. It indicates that the chemical fertilization promote the plant growth includ- 
ing roots which in turn enhance the absorption of soil nutrients especially N. In contrast, in manure application, soil microorganisms use up the inorganic soil nitrogen to decompose the organic matter by the process known as $\mathrm{N}$ immobilization. Therefore, nutrients accumulation was comparatively lower in manure application than chemical fertilization.

Pot study has some restraint such as root growth due to limited soil volume compared to field experiment in which larger root growth and higher plant nutrient uptake were observed. But, in the case of estimation of apparent nutrient recovery, pot study provided the lesser factors affecting the plant nutrient uptake and gave more accurate recovery percentage of applied manure and fertilizer however, more investigation will be necessary. The decreasing of apparent nutrient recovery percentage with increasing application rate was reported by Culley et al. (1981), Motavalli et al. (1989) and Cusick et al. (2006). In our study, the same pattern of decreasing was observed except in AKR of Kasuya soil. We estimated that $\mathrm{N}$ availability was $30 \%$ of total $\mathrm{N}$ for $\mathrm{CM}$ and $70 \%$ for PM, but ANR percentages for both manures were low although additional basal urea application was carried out. ANR of CM application for both soils was ranging form 4.6 to $16.9 \%$ while that of PM application was rather stable and range from 39.7 to $50.7 \%$. The very low $\mathrm{N}$ recovery for CM in Futsukaichi soil may be due to the low readily available N content. ANR\% of J-std was 120.2 and $125.0 \%$ in Kasuya and Futsukaichi soil, respectively and it is evidence that the plant absorbed $\mathrm{N}$ not only from application but also form the soil $\mathrm{N}$ pool such as decomposition of previous year residue (stubbles). Plant $\mathrm{P}$ accumulation in CM treatments was half of that in PM (Table 4) although total $\mathrm{P}$ application in $\mathrm{CM}$ was one third of that in PM (for example P applied amount in CM1 was $131.3 \mathrm{mg} \mathrm{pot}^{-1}$ while that in PM1 was $384.3 \mathrm{mg} \mathrm{pot}^{-1}$ ). In both soils, very low APR was observed in all application treatments expect J-std, however higher APR\% was observed in CM application compared to PM. It can be considered that soil microbial biomass, which was increased in CM application because of its higher $\mathrm{C}$ content, might promote the $\mathrm{P}$ availability in $\mathrm{CM}$ as a result in utilization of $\mathrm{P}$ from soil $\mathrm{P}$ component. The superiority of composed cattle manure (CM) application on P availability was also reported in Eghball and Power (1999). The AKR\% was relatively high in all application treatments and that in J-std was 404.6 and 398.3\% in Kasuya and Futsukaichi soil, respectively. It indicates that AKR\% in this study might not be depend only on the application but form soil $\mathrm{K}$.

$\mathrm{N}$ input-output balance is very important for a biomass and yield accumulation of a crop as well as for the uptake of other plant essential nutrients. In Fig. 5, the input-output of $\mathrm{N}$ of rice cultivation with manure application in two soils was shown. In both soils, the inputoutput values are positive and higher in CM applications and lower in PM application while almost negative in UF and J-std. It indicates that the plant $\mathrm{N}$ uptake in UF and J-std was exceeded over the application amount by taking up the original soil N. Moreover, higher amount of

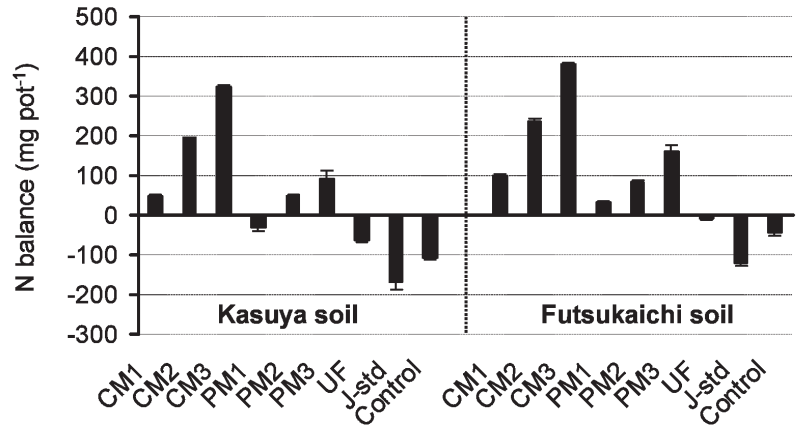

Fig. 5. Nitrogen balance (applied N-total plant $N$ accumulation) in rice at 2007 pot study by different manure and fertilizer application.

application will be needed to get the sustainable amount of yield in proceeding year. Larger values of $\mathrm{N}$ balance in $\mathrm{CM}$ applications indicate that plant removal is lower than the application amount and therefore, soil may retain the certain amount of organic nitrogen (Fig. 5). Therefore, it is impossible to get the optimal yield and sustainable production, without understanding the input-output balance and estimating to apply the accurate amount for plant removal.

Decomposition patterns of organic materials in soil differ markedly and depend primarily on their carbon to nitrogen $(\mathrm{C} / \mathrm{N})$ ratios. Generally, the higher the ratio, the slower the rate of decomposition is. Organic materials with a low $\mathrm{C} / \mathrm{N}$ ratio easily release $\mathrm{N}$ when decomposed by microbes, while those with a high $\mathrm{C} / \mathrm{N}$ ratio apparently require additional $\mathrm{N}$ for the process of decomposition, because decomposers need more available $\mathrm{N}$ for their growth than that contained in the organic materials. By contrast, organic materials with a high $\mathrm{C} / \mathrm{N}$ ratio are likely to compete with crops for $\mathrm{N}$, which can lead to $\mathrm{N}$ deficiency in extreme cases (Suzuki, 1997). In our study, although dry matter, harvested seed yield and nutrient accumulation in CM were better than those in control (Fig. 3, 4 and Table 4), those were very low compared to other treatments. Therefore, only CM application may not produce an optimal rice yield. Low recover of cattle (cow) manure compost $\mathrm{N}$ by rice plant was reported in many article including Uenosono et al. (2004) and Nishida et al. (2005).

Nishida (2004) reported that cattle (cow) manure compost did not increase the dry matter weight and $\mathrm{N}$ uptake by rice at the time of the first application. However, it was observed that the rice yield increased after more than 3 years of successive applications (Ohyama et al., 1998: Uenosono and Nagatomo, 1998). Sahrawat (2005) indicated that soil fertility and nutrient supplying capacity of a soil can be maintained on a longterm basis only by replenishing, by addition through external inputs, nutrients removed by cropping and those lost through physical, chemical and biological processes. In our study, the poor fertility Futsukaichi soil had very low dry matter and seed yield compared to Kasuya soil in previous years (Myint et al., 2009). However, the seed yields had become comparable between the soils with same treatments in three year successive cultiva- 
tion. The adequate application of fertilizers or manures will be necessary even in the high fertility soil to cover the plant removal, hence, to sustain the optimal production. However, in our study, the highest production still has not obtained in manure applications in comparison to J-std. Moreover, it is needed to precede the long term application of suitable organic manure (such as PM) to improve the soil fertility and productivity.

In this day and age, to accomplish the growing demand of increasing population and to improve the nation economy, it becomes important to produce higher yields, as the same time with less environmental impacts. Therefore, the use of high yielding variety such as Manawthuka and environmentally strong fertilizer and manure application system are necessary to increase the yield per unit area. From this study, the PM mixed application was recommended to be suitable for environmental sustainability and optimal yield. To upgrade this property for increasing crop production, long term practice with suitable management procedure for well decomposition will be promising, however further investigations are necessary.

\section{REFERENCES}

Buresh, R. J., W. M. Larazo, E. V. Laureles, M. I. Samson and M. F. Pampolino 2005 Sustainable Soil Management in Lowland Rice Ecosystems. In "Organic-based Agriculture for Sustained Soil Health and Productivity. Proceedings of the $9^{\text {th }}$ PSSST annual scientific conference", Central Luzon State University, Science City of Muñoz, Nueva Ecija, Philippines, pp. $116-125$

Castellanos, J. Z. and P. F. Pratt 1981 Mineralization of manure nitrogen-Correlation with laboratory indexes. Soil Sci. Soc. Am. J. 45: 354-357

Cataldo, D. A., L. E. Schrader and V. L. Youngs 1974 Analysis by digestion and colorimetric assay of total nitrogen in plant tissues high in nitrate. Crop Science 14: 854-856

Culley, J. L. B., P. A. Phillips, F. R. Hoare and N. K. Patni 1981 Soil chemical properties and removal of nutrients by corn resulting form different rates and timing of liquid dairy manure applications. Can. J. Soil Sci. 61: 35-46

Cusick, P. R., K. A. Kelling, J. M. Powell and G. R. Muñoz 2006 Estimates of residual dairy manure nitrogen availability using various techniques. J. Environ. Qual. 35: 2170-2177

Eghball, B and J. F. Power 1999 Phosphours- and nitrogenbased manure and compost applications: Corn production and soil phosphorus. Soil Sci. Soc. Am. J. 63: 895-901

Hossain, M. and V. P. Singh 2000 Fertilizer use in Asian agriculture: implications for sustaining food security and the environment. Nutr. Cycl. Agroecosyst. 57: 155-169

Hussain, F., K. F. Bronson, Y. Singh, B. Singh and S. Peng 2000 Use of chlorophyll meter sufficiency indices for nitrogen management of irrigated rice in Asia. Agron. J. 92: 875-897

Kelling, K. A., L. G. Bundy, S. M. Combs and J. B. Peters 1998 Soil test recommendations for field, vegetable and fruit crops. Univ. of Wisconsin-Extension Bull. A2809

Ladha, J. K. and M. B. Peoples 1995 Management of biological nitrogen fixation for the development of more productive and sustainable agriculture systems: Preface. Plant Soil 174: 1

Ladha, J. K., D. Dawe, T. S. Ventura, U. Singh, W. Ventura and I. Watanabe 2000 Long-term effects of urea and green manure on rice yields and nitrogen balance. Soil Sci. Soc. Am. J. 64: 1993-2001

Ladha, J. K., F. J. de Bruijn and K. A. Malik 1997 Introduction: Assessing opportunities for nitrogen fixation in rice - a frontier project. Plant Soil 194: 1-10

Motavalli, P. P., K. A. Kelling and J. C. Converse 1989 First-year nutrient availability from injected dairy manure. J. Environ. Qual. 18: 180-185

Muramoto, J., I. Goto and M. Ninaki 1992 Rapid analysis of exchangeable cation and cation exchange capacity (CEC) of soils by shaking extraction method. Jpn. J. Soil Sci. Plant Nutr. 63: 210-215 (in Japanese with English summary)

Murphy, J. and J. Riley. 1962 A modified Single Solution for the Determination of Phosphate in Natural Waters. Anal. Chim. Acta. 27: 31-36

Myint, A. K., T. Yamakawa, T. Zenmyo, H. T. B. Thao and P. S. Sarr 2009 Effects of organic manure application on growth, grain yield and N, P and $\mathrm{K}$ recoveries of rice (Oryza sativa L.) variety Manawthuka in different-fertility paddy soils. Comm. Soil Sci. Plant Anal. (in submission)

Nishida, M. 2004 Application of livestock waste compost for forage paddy rice. In "Agriculture, and Soils and Fertilizers in Kyushu and Okinawa”, Kyushu Branch of Jpn. Soc. Soil Sci. Plant Nutr., Fukuoka, pp. 97-98 (in Japanese)

Nishida, M., M. Moriizumi and K. Tsuchiya 2005 Changes in the $\mathrm{N}$ recovery process from ${ }^{15} \mathrm{~N}$-labeled swine manure compost and rice bran in direct-seeded rice by simultaneous application of cattle manure compost. Soil Sci. Plant Nutr. $\mathbf{5 1}$ $577-581$

Ohyama, N., M. Katono and T. Hasegawa 1998 Effects of long term application of organic materials to the paddy field originated form Aso volcanic ash on the soil fertility and rice growth. I. Effects on the rice growth and nutrient uptake for the initial three years. Proc. Facul. Agric. Kyushu Tokai Univ. 17: 9-24 (in Japanese with English summary)

Ohyama, T., M. Ito, K. Kobayashi, S. Araki, S. Yasuyoshi, O. Sasaki, T. Yamazaki, K. Soyama, R. Tanemura, Y. Mizuno and T. Ikarashi 1991 Analytical procedures of N, P, K contents in plant and manure materials using $\mathrm{H}_{2} \mathrm{SO}_{4}-\mathrm{H}_{2} \mathrm{O}_{2}$ Kjeldahl digestion method. Jpn. Bull. Facul. Agric. Niigata Univ. 43: 110-120 (in Japanese with English summary)

Peng, S., F. V. Garcia, R. C. Laza, A. L. Sanico, R. M. Visperas and K. G. Cassman 1996 Increased N-use efficiency using a chlorophyll meter on high-yielding irrigated rice. Field Crop Res. 47: 243-252

Peng, S., J. Yang, F. V. Carcia, R. C. Laza, R. M. Visperas, A. L Sanico, A. Q. Chavez and S. S. Virmani 1998 Physiologybased crop management for yield maximization of hybrid rice. In "Advance in hybrid rice technology - Proceeding of the $3^{\text {rd }}$ international symposium on hybrid rice", IRRI, Los Baños, Philippines, pp. 157-176

Sahrawat, K. L 2004 Organic matter accumulation in submerged soils. Adv. Agron. 81: 169-201

Sahrawat, K. L. 2005 Fertility and organic matter in submerged rice soils. Current Science 88: 735-739

Savant, N. K. and S. K. DeDatta 1982 Nitrogen transformations in wetland rice soils. Adv. Agron. 35: 241-302

Sims, J. T. and D. C. Wolf 1994 Poultry waste management: Agricultural and environmental issues. Adv. Agron. 52: 2-83

Suzuki, A. $1997 \quad$ Fertilization of rice in Japan. Japan FAO Association, Tokyo, Japan

Takahashi, S., S. Uenosono and M. Nagatomo 2004 Rice uptake of nitrogen form aerobically and anaerobically composted poultry manure. J. Plant Nutr. 27: 731-741

Takebe, M., T and Yoneyama 1989 Measurement of leaf color scores and its implication to nitrogen nutrition of rice plants. Jpn. Agric. Res. Q. 23: 86-93

Turner, F. T. and M. F. Jund 1994 Assessing the nitrogen requirements of rice crops with a chlorophyll meter. Aust. $J$. Exp. Agr. 34: 1001-1005

Uenosono, S. and M. Nagatomo 1998 Effect of application of only manure on yield and quality of paddy rice. Kyushu Agric. Res. 60: 56 (in Japanese)

Uenosono, S., M. Nagatomo, S. Takahashi, E. Kunieda and S. Yamamuro 2004 Evaluation of nitrogen availability of composted poultry and sawdest cattle manures labeled with ${ }^{15} \mathrm{~N}$ on paddy field rice. Jpn. J. Soil Sci. Plant Nutr. $\mathbf{7 5}$ 313-319 (in Japanese with English summary) 
